\title{
Phytoplankton size structure during and after the 1997/98 El Niño in a coastal upwelling area of the northern Humboldt Current System
}

\author{
José Luis Iriarte ${ }^{1,2, *}$, Humberto E. González ${ }^{3,4}$ \\ ${ }^{1}$ Instituto de Acuicultura, Universidad Austral de Chile, PO Box 1327, Puerto Montt, Chile \\ ${ }^{2}$ Programa Doctorado, Departamento de Oceanografía, and ${ }^{3}$ Centro de Investigaciones Oceanográficas del Pacífico \\ Sur-Oriental (COPAS), Universidad de Concepción, PO Box 160-C, Concepción, Chile \\ ${ }^{4}$ Instituto de Biología Marina, Universidad Austral de Chile, PO Box 567, Campus Isla Teja, Valdivia, Chile
}

\begin{abstract}
Primary production (PP) and phytoplankton biomass changes in an intense upwelling

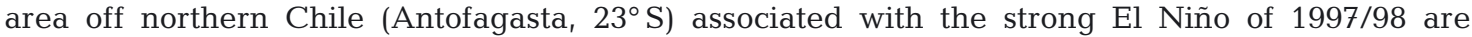
described over a 5 yr sampling period. The oceanographic anomalies observed during July 1997 and January 1998, associated with the intrusion of warmer oligotrophic waters to the coast, reduced the upwelling of cold, nutrient-rich waters in the upper $100 \mathrm{~m}$. An oligotrophic regime seems to have resulted in a higher dominance ( 45 to $70 \%$ ) of pico- and nanoplankton in inshore areas during summer/winter 1997 and summer 1998, with values of biomass and PP of $5 \mathrm{mg} \mathrm{chl} \mathrm{a} \mathrm{m}{ }^{-3}$ and $2.0 \mathrm{~g} \mathrm{C} \mathrm{m}^{-2}$ $\mathrm{d}^{-1}$, respectively. After that period, when the frequent upwelling of cold, nutrient rich water was reestablished along the coast off Antofagasta, biomass and PP estimates increased up to $80 \mathrm{mg} \mathrm{chl} \mathrm{a} \mathrm{m^{-3 }}$ $\left(\right.$ mean $=25.5 \mathrm{mg} \mathrm{chl} a \mathrm{~m}^{-3}$ ) and $12 \mathrm{~g} \mathrm{C} \mathrm{m}^{-2} \mathrm{~d}^{-1}$ (mean $=6.5 \mathrm{~g} \mathrm{C} \mathrm{m}^{-2} \mathrm{~d}^{-1}$ ), respectively. During that period, the microphytoplankton size fraction accounted for $>50 \%$ of the biomass and productivity. Sedimentation trap studies showed that the sedimentation rate of diatoms was very low during El Niño conditions (January 1997 and 1998) with values between 0.02 and $0.2 \mathrm{mg} \mathrm{C} \mathrm{m}^{-2} \mathrm{~d}^{-1}$, increasing by 2 orders of magnitude during winter and spring 2001 (mean $=28 \mathrm{mg} \mathrm{C} \mathrm{m}^{-2} \mathrm{~d}^{-1}$ ). The data showed that during 1997/98 El Nino event, pico-and nanophytoplankton size classes made a significant contribution to the production and may thus represent an alternative energy-flow pathway within this upwelling area.
\end{abstract}

KEY WORDS: Primary production $\cdot$ El Niño 1997/98 $\cdot$ Size distribution

\section{INTRODUCTION}

The frequent upwelling of cold, nutrient-rich water along the northern coast of Chile (off Antofagasta) during most of the year (Rodríguez et al. 1991, Marín \& Olivares 1999, Thomas et al. 2001, Ulloa et al. 2001) produces a highly productive phytoplankton assemblage, dominated by chain-forming diatoms, which supports a large commercial fishery. During the 1997/98 El Niño event in July 1997, warm equatorial waters moved to the coast, and reduced the upwelling of nutrient-rich waters in the upper $100 \mathrm{~m}$ to a narrow coastal band $(<15 \mathrm{~km})$ (González et al. 1998). During this event, the pico- and nanophytoplankton size classes dominated both oceanic and coastal stations off Antofagasta and accounted for $67 \%$ of the primary production (PP) and chl a biomass (Iriarte et al. 2000).

Phytoplankton of different size fractions produce different types of organic nutrients which could support different pathways of materials in the food web (Legendre \& Rassoulzadegan 1995). In marine ecosystems, the smaller phytoplankton (less than $2.0 \mu \mathrm{m}$ ) fuel the microbial food web within the photic layer, while larger microphytoplankton (greater than $20 \mu \mathrm{m}$ ) are an 
important component of the 'classical' food chain, furnishing with energy large pelagic and benthic organisms. Most of the phytoplankton in this area are larger than $20 \mu \mathrm{m}$ and their detritus is abundant in the sediment (up to $800 \times 10^{6}$ diatom valves $\mathrm{g}^{-1}$, Ortlieb et al. 2000). Ortlieb et al. (2000) pointed out that high microphytoplankton abundances in the sediment record correlate positively with intense/more frequent upwelling events (higher PP) and negatively with El Niño conditions (lower PP). On the other hand, smallsized phytoplankton $(<20 \mu \mathrm{m})$ predominate in oligotrophic and high nutrient, low chlorophyll (HNLC) regions (Chavez 1989), as well as in some coastal waters (Hall \& Vincent 1990). In these areas small phytoplankton should also contribute to the flux of particles leaving the euphotic zone via macrozooplankton fecal pellets in coastal environments (Urban et al. 1993), as well as fuelling the microbial loop via protozoan grazing (Rassoulzadegan \& Sheldon 1986).

Time-series observations are useful for documenting the consequences of climatic-driven oceanographic events (e.g. El Niño phenomena) and also for establishing baseline conditions for long-term studies in coastal ecosystems.

The aim of this study was to assess the changes in size-fractionated PP, biomass, and the sedimentation rate of phytoplankton in a coastal area, the Bay of Mejillones (Antofagasta, Chile, 23 $\mathrm{S}$ ), resulting from the El Niño of $1997 / 98$ and the period following this event. Data were obtained during 8 visits to the area over a 5 yr period that included the El Niño of 1997/98 (Fig. 1). This allowed us to compare the temporal distribution of 3 phytoplankton size classes, to assess the consequences of the El Niño on the size structure of phytoplankton assemblages as well as the contribution of the dominant group to the downward carbon flux.

\section{MATERIALS AND METHODS}

Chl $a$ and PP of 3 size fractions, pico-, nano-, and micro-phytoplankton, were measured in the coastal

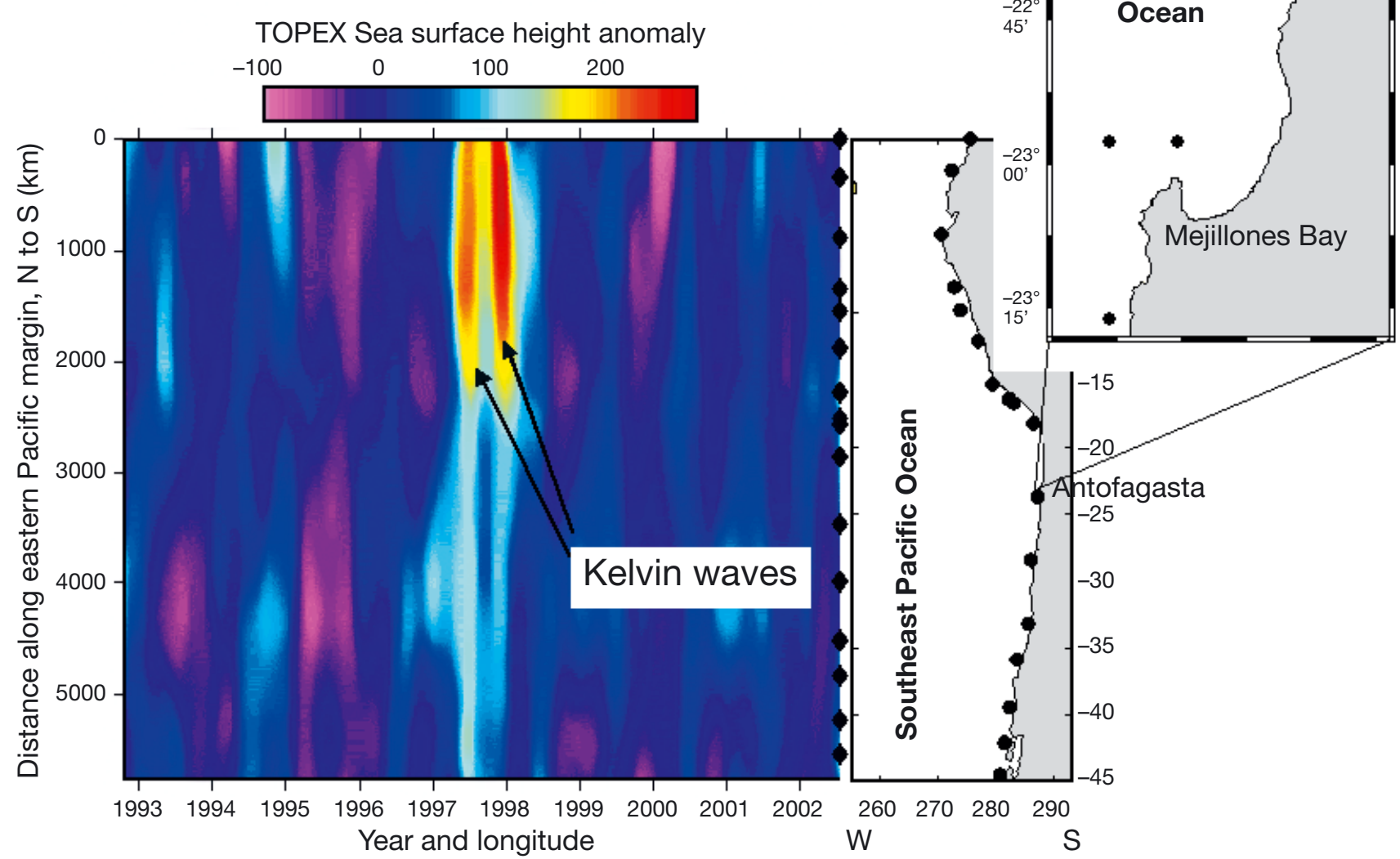

Fig. 1. Time series of sea surface height anomaly $(\mathrm{cm})$ image of the eastern Pacific region. Shown is the site of sampling, Antofagasta (in the upper $200 \mathrm{~m}$ depth of continental shelf) and the signal of equatorial Kelvin waves (KW) travelling along the northern coast off Chile during the 1997/98 El Niño Event. Three closed symbols on the insert map represent the sampling stations for the present study. Diamonds and closed symbols along the coastline represent locations from where TOPEX data were extracted 
waters off Antofagasta, Bahía de Mejillones (23 $\mathrm{S})$ during 8 research cruises: summer 1997 (1 to 31 January), winter 1997 (1 to 24 July, El Niño event), summer 1998 (15 to 20 January), spring 2000 (19 to 23 October), summer 2001 (2 to 11 February), winter 2001 (1 to 11 August), spring 2001 (20 to 30 October) and summer 2002 (20 to 25 January). The first 3 cruises occurred during El Niño and the remainder followed the event.

Water samples were collected at 3 coastal stations (Fig. 1) using 5-L PVC Go-Flo water-sampling bottles, at 3 depths within the euphotic zone: surface, subsurface chl a maximum, and the $2 \%$ light penetration depth. The 3 stations roughly correspond to those defined as coastal stations in Iriarte et al. (2000), where significant differences between stations in integrated total chl a were not detected (ANOVA test: $F=0.148$, $\mathrm{p}=0.706$; Pizarro et al. 2002). The sampling depths were selected to characterize the phytoplankton variability in the upper $25 \mathrm{~m}$ depth, defined as the depth of the euphotic zone (Marin \& Olivares 1999).

Water samples for primary production determinations were incubated in $100 \mathrm{ml}$ borosilicate glass bottles ( 2 clear replicate bottles and 1 dark bottle at each depth) and placed in a natural-light incubator for $4 \mathrm{~h}$ (mainly between 10:00 and 14:00 h). Temperature was regulated by running surface seawater over the incubation bottles. For the subsurface chl a maximum and $2 \%$ light penetration depth incubation, light intensity was attenuated using a screen to approximate light at the depth where the water was collected. The extent of light (photosynthetically active radiation; PAR) penetration was determined using submersible sensors (QSP 200-D, Biospherical Instruments). Sodium bicarbonate $\left(40 \mu \mathrm{Ci} \mathrm{NaH}{ }^{14} \mathrm{CO}_{3}\right)$ was added to each bottle. Following incubation, samples were manipulated under subdued light conditions during pre- and postincubation periods. The contents were filtered according to the fractionation procedures mentioned below. Filters $(0.7$ and $2.0 \mu \mathrm{m})$ were placed in $20 \mathrm{ml}$ borosilicate scintillation vials and kept at $-15^{\circ} \mathrm{C}$ until readings were taken (15 d later). To remove excess inorganic carbon, filters were treated with $\mathrm{HCl}$ fumes for $4 \mathrm{~h}$. A scintillation cocktail (10 ml Ecolite) was added to vials and radioactivity was determined in a scintillation counter (Beckmann). Depth-integrated values of PP ( $\mathrm{mg} \mathrm{C} \mathrm{m}^{-2} \mathrm{~h}^{-1}$ ) were calculated using trapezoidal integration over the euphotic zone (3 depths: surface, subsurface chl a maximum, and the $2 \%$ of surface irradiance depth). Integrated production rates per hour were multiplied by daily light hours for Antofagasta (Arata 1980). Phytoplankton size fractionation was performed post-incubation in 3 sequential steps: (1) for the nanoplankton fraction $(2.0$ to $23 \mu \mathrm{m})$, seawater $(100 \mathrm{ml})$ was pre-filtered using $23 \mu \mathrm{m}$ Nitex mesh and collected on a
$2.0 \mu \mathrm{m}$ Nuclepore; (2) for the picoplankton fraction $(0.7$ to $2.0 \mu \mathrm{m})$, seawater $(100 \mathrm{ml})$ was pre-filtered using a $2.0 \mu \mathrm{m}$ Nuclepore and collected on a $0.7 \mu \mathrm{m}$ MFS (microfiltration system) glass-fiber filter; (3) for the whole phytoplankton community, $100 \mathrm{ml}$ of seawater was filtered through a $0.7 \mu \mathrm{m}$ MFS glass-fiber filter. The micro-phytoplankton fraction was obtained by subtracting the production estimated in Steps 1 and 2 from the production estimated in Step 3.

Size-fractionated chl a was measured at the same stations and depths where PP experiments were carried out. Seawater samples $(150 \mathrm{ml})$ were filtered and analysed using a digital Turner AU-10 fluorometer as recommended by Parsons et al. (1984). The sizefractionated procedure was the same as for PP (Nuclepore and MFS glass fiber filters). Depth-integrated

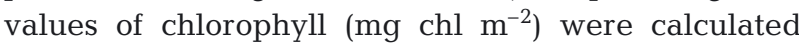
using trapezoidal integration over the euphotic zone (3 depths: surface, subsurface chl a maximum, and the $2 \%$ of surface irradiance depth). Measurements of PP $\left(\mathrm{mg} \mathrm{C} \mathrm{m} \mathrm{m}^{-3} \mathrm{~h}^{-1}\right)$ and chl a $\left(\mathrm{mg} \mathrm{m}^{-3}\right)$ were averaged within the euphotic zone for each station.

Samples for phytoplankton cell-counts consisted of $300 \mathrm{ml}$ subsamples, which were stored in clear plastic bottles and fixed and preserved in $1 \%$ Lugol iodine solution. From each sample, a $50 \mathrm{ml}$ subsample was placed and left to settle for $30 \mathrm{~h}$ in a sedimentation chamber, the bottom of which was observed using an inverted microscope (Hasle 1978). The phytoplankton carbon biomass was estimated from the following nonlinear equations: for athecate dinoflagellates $\mathrm{C}=$ 0.109(Biovolume) ${ }^{0.991}$ (Montagnes et al. 1994); for flagellates $\mathrm{C}=0.433$ (Biovolume) ${ }^{0.863}$ (Verity et al. 1992) For diatoms, nonlinear equations for vacuolate and nonvacuolate algae were used, following Smayda's (1978) recommendations.

Vertical flux and phytoplankton carbon. The vertical flux of particulate matter was measured using paired cylindrical sediment traps (modified from Gundersen 1991) with a $122 \mathrm{~cm}^{2}$ catchment area and a height diameter ratio of 8.3. Traps were deployed in a drifting mode at 50 and $100 \mathrm{~m}$ depths for periods ranging between 1 and $2 \mathrm{~d}$. Before deployment, $1 \mathrm{ml}$ of saturated $\mathrm{HgCl}_{2}$ solution was added per $250 \mathrm{ml}$ of sample solution (GF/F-filtered seawater) to retard bacterial activity in the trap material (Lee et al. 1992).

Subsamples from the traps were taken for estimations of dominant microplankton taxa using standard microscopic methods (Utermöhl 1958). Phytoplankton carbon, based on cell volume, were estimated after counting and sizing the different species according to Edler (1979). A statistical test of non-parametric correlation (Zar 1984) was performed in order to detect tendencies and relationships among variables (biomass, PP). 


\section{RESULTS AND DISCUSSION}

The 1997/98 El Niño event was one of the strongest recorded over the past century (McPhaden 1999), causing climatic disturbances around the world. Chavez et al. (2002), while discussing the temporal evolution of the El Niño of 1997/98 around the coasts of Ecuador, Peru and northern Chile, suggested that the sea level began to rise in April 1997 and lasted until May 1998, with a maximum in late 1997. Large fluctuations in the depth of the thermocline in Antofagasta (Sobarzo \& Figueroa 2001) between July 1997 and January 1998 were associated with the passage of remotely wind-forced equatorial Kelvin waves (Fig. 1). During the El Niño of 1997/98 in northern Chile, oceanographic conditions were characterized by a warm anomaly ( 1 to $6^{\circ} \mathrm{C}$ in the upper $100 \mathrm{~m}$ ), high stratification, low nitrate concentration in the upper 10 m depth $(<5 \mu \mathrm{M})$, low orthophosphate $(<0.5 \mu \mathrm{M})$ and silicate $(<2 \mu \mathrm{M})$, and deepening of the thermocline (up to $200 \mathrm{~m}$ depth) and oxycline (below $50 \mathrm{~m}$ depth) near the coast (González et al. 2000, Iriarte et al. 2000). Nutrients concentrations from Mejillones Bay, measured during 'normal' oceanographic conditions, showed annual average concentration of $\mathrm{PO}_{4}{ }^{3-}$ and $\mathrm{NO}_{3}{ }^{-}$in the euphotic zone of 2.03 and $10 \mu \mathrm{M}$ (range: $1-16 \mu \mathrm{M}$ ), respectively (Rodriguez et al. 1991).

During the El Niño winter 1997 and summer 1998, PP of ca. $1.8 \mathrm{~g} \mathrm{C} \mathrm{m}^{-2} \mathrm{~d}^{-1}$ was only $1 / 3$ of that in summer and winter 2001. After the El Niño event, PP values ranged from 1.1 to $8.1 \mathrm{~g} \mathrm{C} \mathrm{m}^{-2} \mathrm{~d}^{-1}$ (Fig. 2), and were comparable to those recorded in upwelling systems such as Perú (1 to $5 \mathrm{~g} \mathrm{C} \mathrm{m}^{-2} \mathrm{~d}^{-1}$; Calienes et al. 1985) and the Benguela ( 0.5 to $4.0 \mathrm{~g} \mathrm{C} \mathrm{m}^{-2} \mathrm{~d}^{-1}$; Brown \& Field 1986). Primary productivity during spring 2000 increased to a mean of ca. $8.0 \mathrm{~g} \mathrm{C} \mathrm{m}^{-2} \mathrm{~d}^{-1}$, an increase of
$400 \%$ over the productivity during the El Niño of winter 1997 (Fig. 2). The time series observations taken during the El Niño of 1992 from warm events along the equatorial Pacific (Barber et al. 1996) and in Central California waters (Chavez et al. 2002) indicated a $50 \%$ decrease in PP and a $70 \%$ reduction in new production, respectively. The satellite-measured chl $a$ and temperature figures in Thomas et al. (2001) indicate that the temperature patterns normally associated with upwelling were absent, and chl a concentrations were lower during the period from winter 1997 to summer 1998. With the exception of spring 2000, the temporal variation in chl a concentration showed a similar pattern compared with PP; values estimated were lowest during summer and winter 1997 (less than $3 \mathrm{mg}$ chl a $\mathrm{m}^{-3}$ ) and highest during winter 2001 (ranging between

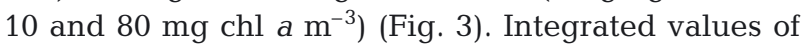

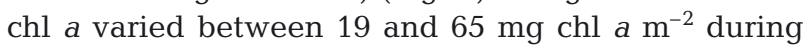

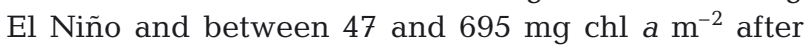
the event with the higher values during February and August 2001 (Table 1). During the upwelling periods (spring 2000 to summer 2002), the increase of PP that occurred in spring 2000 could not be the result of an increase in phytoplankton biomass (Fig. 3), and it would imply that a physiological factor such as light availability, temperature or nutrient supply was modulating the PP.

The mean primary production estimates of different size fractions in each cruise are presented in Table 1. The $>23 \mu \mathrm{m}$-fraction production ranged from 0.29 to $26 \mathrm{mg} \mathrm{C} \mathrm{m}{ }^{-3} \mathrm{~h}^{-1}$. The $<2 \mu \mathrm{m}$ and 2 to $23 \mu \mathrm{m}$-fractions productions varied from 0.99 to $3.26 \mathrm{mg} \mathrm{C} \mathrm{m}^{-3} \mathrm{~h}^{-1}$ and from 0.21 to $12 \mathrm{mg} \mathrm{C} \mathrm{m}^{-3} \mathrm{~h}^{-1}$, respectively. Microphytoplankton biomass and PP are usually high in the study area (Marín \& Olivares 1999). However, during El Niño, the pico- and nanophytoplankton $(<23 \mu \mathrm{m})$

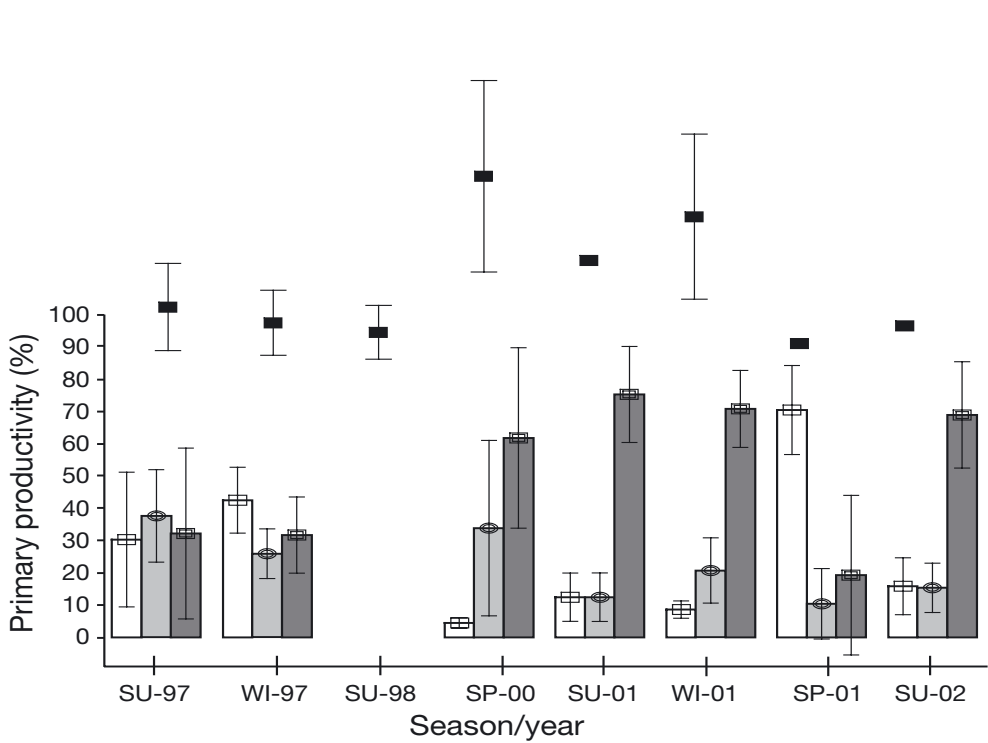

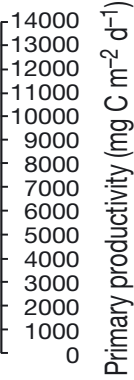

Fig. 2. Total (mg C m $\left.\mathrm{m}^{-2} \mathrm{~d}^{-1}\right)$ and size-fractionated (\%) primary production of picoplankton (white bars), nanoplankton (light gray bars) and microphytoplankton (dark grey bars) during the El Niño event (1997/98) and non-El Niño period $(2000 / 02)$ in coastal waters of Bahía Mejillones (mean $\pm 1 \mathrm{SD}$ ). Values were taken from 3 coastal stations on the upper continental shelf $(<200 \mathrm{~m}$ depth). $X$-axis: SU, summer; SP, spring; WI, winter 
Table 1. Mean values of primary productivity and chl a estimates from the photic layer of each size fraction from coastal waters off Antofagasta ( $\pm 1 \mathrm{SD} ; \mathrm{n}=$ number of samples)

\begin{tabular}{|c|c|c|c|c|c|c|c|}
\hline \multirow[t]{2}{*}{ Cruise } & \multirow{2}{*}{$\begin{array}{c}\text { Primary } \\
\left(\mathrm{mg} \mathrm{C} \mathrm{m}^{-3} \mathrm{~h}^{-1}\right) \\
<2.0 \mu \mathrm{m}\end{array}$} & \multirow{2}{*}{$\begin{array}{l}\text { Productivity } \\
\qquad 2-23 \mu \mathrm{m}\end{array}$} & \multicolumn{4}{|c|}{$\begin{array}{c}\mathrm{Chl} a \\
\left(\mathrm{mg} \mathrm{chl} a \mathrm{~m}^{-3}\right)\end{array}$} & \multirow[t]{2}{*}{$\begin{array}{c}\text { Chl } a \\
\left(\mathrm{mg} \mathrm{chl} a \mathrm{~m}^{-2}\right)\end{array}$} \\
\hline & & & $>23 \mu \mathrm{m}$ & $<2.0 \mu \mathrm{m}$ & $2-23 \mu \mathrm{m}$ & $>23 \mu \mathrm{m}$ & \\
\hline January 1997 & $\begin{array}{c}1.99 \\
(1.17 ; \mathrm{n}=30)\end{array}$ & $\begin{array}{c}5.32 \\
(7.16)\end{array}$ & $\begin{array}{c}7.67 \\
(10.27)\end{array}$ & $\begin{array}{c}0.66 \\
(0.70)\end{array}$ & $\begin{array}{c}0.59 \\
(0.61)\end{array}$ & $\begin{array}{c}1.35 \\
(3.18)\end{array}$ & 65 \\
\hline July 1997 & $\begin{array}{c}1.99 \\
(1.28 ; \mathrm{n}=18)\end{array}$ & $\begin{array}{l}1.30 \\
(1.04)\end{array}$ & $\begin{array}{c}1.52 \\
(1.35)\end{array}$ & $\begin{array}{c}0.32 \\
(0.19)\end{array}$ & $\begin{array}{c}0.15 \\
(0.12)\end{array}$ & $\begin{array}{c}0.26 \\
(0.19)\end{array}$ & 19 \\
\hline October 2000 & $\begin{array}{c}1.61 \\
(0.81 ; \mathrm{n}=6)\end{array}$ & $\begin{array}{l}12.29 \\
(10.18)\end{array}$ & $\begin{array}{l}20.39 \\
(7.57)\end{array}$ & $\begin{array}{c}0.50 \\
(0.24)\end{array}$ & $\begin{array}{c}6.92 \\
(4.51)\end{array}$ & $\begin{array}{c}1.48 \\
(1.36)\end{array}$ & 115 \\
\hline February 2001 & $\begin{array}{c}1.28 \\
(0.84 ; \mathrm{n}=6)\end{array}$ & $\begin{array}{c}1.27 \\
(0.88)\end{array}$ & $\begin{array}{c}15.30 \\
(17.93)\end{array}$ & $\begin{array}{c}1.82 \\
(1.80)\end{array}$ & $\begin{array}{c}1.30 \\
(1.52)\end{array}$ & $\begin{array}{c}14.36 \\
(15.46)\end{array}$ & 585 \\
\hline August 2001 & $\begin{array}{c}3.26 \\
(2.43 ; \mathrm{n}=14)\end{array}$ & $\begin{array}{c}8.65 \\
(8.48)\end{array}$ & $\begin{array}{c}26.26 \\
(15.37)\end{array}$ & $\begin{array}{c}4.40 \\
(3.93)\end{array}$ & $\begin{array}{c}5.60 \\
(3.72)\end{array}$ & $\begin{array}{c}35.74 \\
(29.80)\end{array}$ & 695 \\
\hline October 2001 & $\begin{array}{c}1.29 \\
(0.54 ; \mathrm{n}=4)\end{array}$ & $\begin{array}{c}0.21 \\
(0.24)\end{array}$ & $\begin{array}{c}0.29 \\
(0.36)\end{array}$ & $\begin{array}{c}0.56 \\
(0.35)\end{array}$ & $\begin{array}{c}0.42 \\
(0.26)\end{array}$ & $\begin{array}{c}1.46 \\
(1.35)\end{array}$ & 47 \\
\hline January 2002 & $\begin{array}{c}0.99 \\
(1.33 ; \mathrm{n}=6)\end{array}$ & $\begin{array}{c}0.96 \\
(1.26)\end{array}$ & $\begin{array}{c}3.43 \\
(2.69)\end{array}$ & $\begin{array}{c}0.92 \\
(0.36)\end{array}$ & $\begin{array}{c}0.99 \\
(0.59)\end{array}$ & $\begin{array}{c}3.38 \\
(1.88)\end{array}$ & 65 \\
\hline
\end{tabular}

were the dominant size classes, and accounted for more than $50 \%$ of chl $a$ and PP in coastal waters (Figs. 2 \& 3). After re-establishment of cold nutrientrich upwelled water, microphytoplankton (>23 $\mu \mathrm{m})$ productivity and biomass was enhanced. Phytoplankton species composition was constant and living carbon biomass remained low during the El Niño (0.03 to

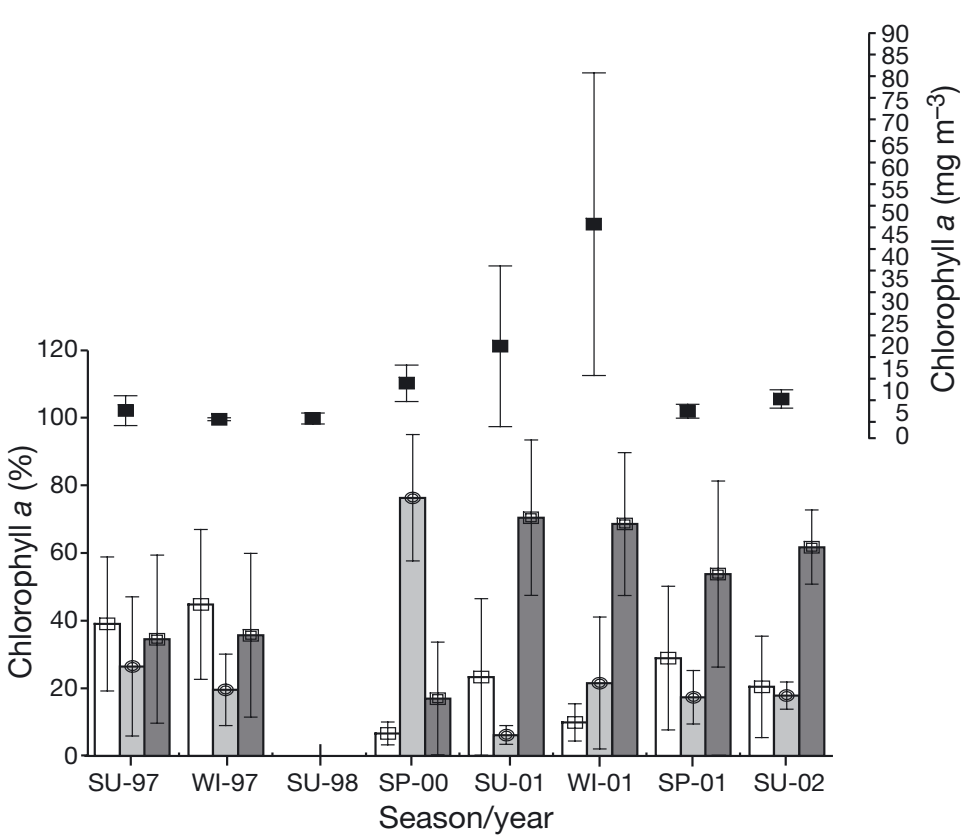

Fig. 3. Total (mg chl $\mathrm{a} \mathrm{m}^{-3}$ ) and size-fractionated (\%) chl a of picoplankton (white bars), nanoplankton (light gray bars) and microphytoplankton (dark gray bars) during the El Niño event (1997/98) and non-El Niño period (2000/02) at coastal waters of Bahía Mejillones (mean $\pm 1 S D)$. Mean values were taken at 3 coastal stations within the euphotic zone (surface: $0 \mathrm{~m}$; chlorophyll maximum depth: $5-10 \mathrm{~m} ; 2 \%$ of surface irradiance: 20-25 m). $x$-axis: SU, summer; SP, spring; WI, winter

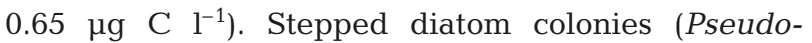
nitzschia cf. delicatissima) and small naked dinoflagellates (Gymnodinium spp., size: 5 to $25 \mu \mathrm{m}$ ) and autotrophic flagellates dominated the phytoplankton assemblages. After El Niño, large living carbon biomass pulses are due to large microphytoplanktonic

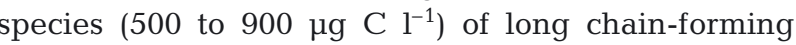
diatoms (>20 $\mu \mathrm{m})$. Chaetoceros spp., Guinardia delicatula, Rhisozolenia spp. Detonula pumila, Eucampia cornuta, formed more than $70 \%$ of the total phytoplankton abundance.

The sedimentation rate of diatoms was very low before (January 1997) and during (July 1998) the El Niño conditions, with values between 0.02 and $0.2 \mathrm{mg} \mathrm{C} \mathrm{m} \mathrm{d}^{-1}$, increasing 2 orders of magnitude during the La Niña in winter and spring 2001 (mean $=28 \mathrm{mg} \mathrm{C}$ $\mathrm{m}^{-2} \mathrm{~d}^{-1}$ ) (Fig. 4). On average, the phytoplankton sedimentation rate was $0.01 \%$ of the PP of coastal waters during the 1997/98 El Niño event, compared with $0.1 \%$ of PP estimated after that period. This data suggests that, although small-sized phytoplankton $(<23 \mu \mathrm{m})$ dominated during the 1997/98 El Niño period, they did not contribute significantly to the flux of carbon biomass leaving the euphotic zone, probably because they are effectively grazed by protozoans (Rassoulzadegan \& Sheldon 1986), and they have low sinking rates (Takahashi \& Bienfang 1983). In the same area, González et al. (2000) showed vertical flux of total particulate organic carbon (POC; as \% PP) before (8\%) and during (9\%) El Niño 1997/98, suggesting that the decrease 


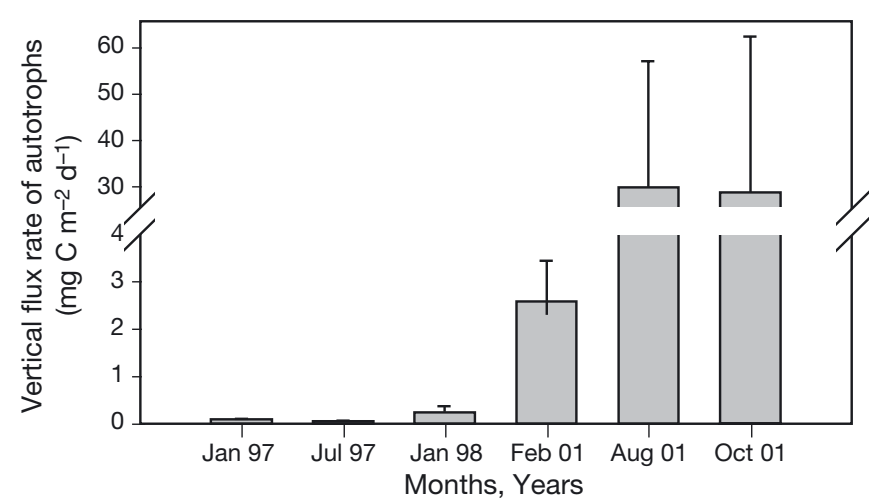

Fig. 4. Phytoplankton sedimentation rates $\left(\mathrm{mg} \mathrm{C} \mathrm{m} \mathrm{m}^{-2} \mathrm{~d}^{-1}\right)$ estimated from 6 cruises during the El Niño event (1997/98) and non-El Niño period (2000/01) in coastal waters of Bahía Mejillones (mean $\pm 1 \mathrm{SD}$ )

in the vertical flux of diatoms (mainly chain-forming diatoms) during El Niño might be compensated by the increase in vertical flux of other type of particulates, such as faecal material. Increased grazing-impact and vertical fluxes of appendicularian faecal pellets (González et al. 2000) and diminished diatom flux by $75 \%$ during El Niño 1997/98 (Romero et al. 2001) give support to this statement.

We suggest that the relatively low export/production rates $(0.01$ to $0.1 \%)$ found in the study area during all sampling periods were a consequence of at least 2 factors: (1) the El Niño of 1997/98 favoured the shift to a microbial loop-based food web over the classical diatom-to-zooplankton food chain and, (2) the strong onshore-offshore variability (e.g. filaments; Sobarzo \& Figueroa 2001) of the upwelling area off the Peninsula of Mejillones.

In the northern Humboldt Current System during El Niño, the vertical flux rate of POC plus mesozooplankton grazing (copepods, euphausiids, and pelagic tunicates) removed a small proportion of the photosynthetically produced POC (from 20 to $30 \%$ ) (González et al. 2000). If less than $1 \%$ of PP is sinking, then an important part of the locally generated POC (70 to $80 \%$ ) might be exported seaward in filaments and eddies. Similar mechanisms were invoked by Olivieri \& Chavez (2000) to explain that a large fraction of the PP was unused within the mixed layer and exported horizontally as ungrazed phytoplankton in the coastal upwelling system of Monterey Bay.

There was a significant positive relationship between pico-, nano-, and microphytoplankton biomass and total chl a $\left(r_{\text {pico }}=0.92 ; r_{\text {nano }}=0.68 ; r_{\text {micro }}=0.99 ; \mathrm{n}=60\right.$, $\mathrm{p}<0.05)$, indicating that absolute biomass in all 3 phytoplankton size classes increased with the return from El Niño (oligotrophic) to more 'normal' (eutrophic) conditions. During El Niño, water with low chl $a$ and low PP tended to have a high proportion of picophytoplankton compared with conditions of high PP ( $\mathrm{r}=$ $-0.76, \mathrm{n}=42, \mathrm{p}<0.05)$ and biomass $(\mathrm{r}=-0.73, \mathrm{n}=54$, $\mathrm{p}<0.05)$. A size-spectrum analysis (Fig. 5) ( $\log _{2} \%$ normalized PP $=\log _{2} a+b \log _{2}$ mean size class) revealed a more negative slope during El Niño 1997/98 ( $b=-0.93$, $\mathrm{p}<0.05)$ than a normal phase $(\mathrm{b}=-0.44, \mathrm{p}<0.05)$, suggesting that an oceanographic shift from cold and nutrient-rich waters to oligotrophic conditions may facilitate the dominance of small size classes, and a significant proportion of PP is fuelling through the microbial food web. Results reported in the upwelling area off Coquimbo $\left(30^{\circ} \mathrm{S}\right.$, Montecino \& Quiroz 2000) suggested that when resources, such as nutrients or light, are limiting, the phytoplanktonic size structure should be displaced toward a smaller size, which is more efficient in using resources than microphytoplankton (Chisholm 1992).

The observed pattern in the changing phytoplankton-community variables associated with El Niño and non-El Niño periods could be explained by the following conceptual model (Fig. 6): (1) During coastal upwelling, the 15 to $16^{\circ} \mathrm{C}$ isotherm reaches the surface, maximizing PP and biomass (up to $12 \mathrm{~g} \mathrm{~m}^{-2} \mathrm{~d}^{-1}$ ) and leading to a community dominated by chain-forming diatoms. This phytoplankton is grazed by medium(copepods) and large- (euphausids) sized zooplankton groups. A significant fraction of the PP may be exported laterally offshore by physical forcing. (2) During

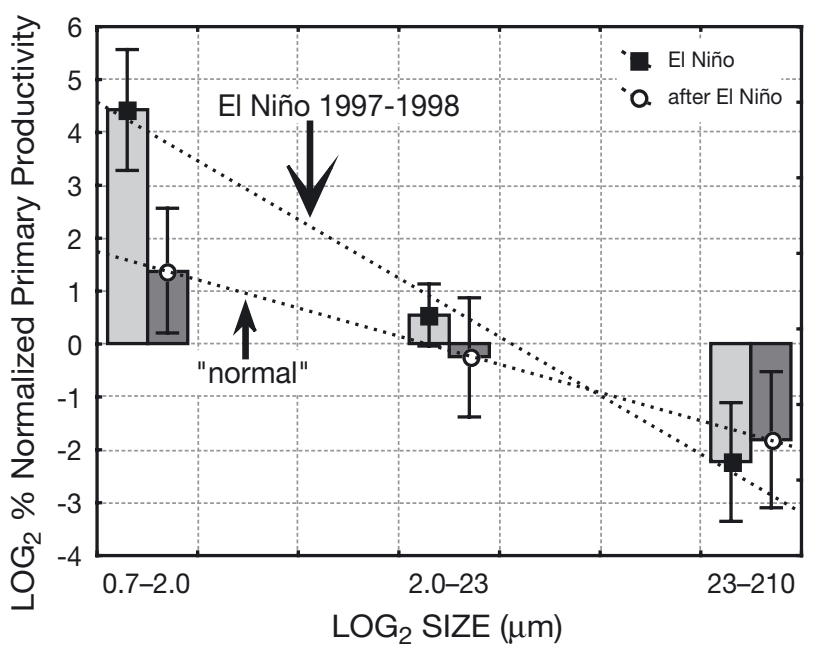

Fig. 5. Relationship between normalized primary productivity estimates $\left(\log _{2} \%\right)$ and 3 size classes $\left(\log _{2} \mu \mathrm{m}\right)$ during the El Niño event (light grey bars) and non El Niño period (dark gray bars) in coastal waters of Bahía Mejillones (mean $\pm 1 \mathrm{SD}$ ). Mean values of primary productivity $\left(\mathrm{mg} \mathrm{C} \mathrm{m}^{-3} \mathrm{~h}^{-1}\right)$ were taken at 3 coastal stations within the euphotic zone (surface: $0 \mathrm{~m}$; chlorophyll maximum depth: $5-10 \mathrm{~m} ; 2 \%$ of surface irradiance: $20-25 \mathrm{~m}$ ). Phytoplankton size classes (on $x$-axis): picoplankton $=0.7-2.0$; nanoplankton $=2.0-23.0 ;$ microplankton $=23-210 \mu \mathrm{m}$ 


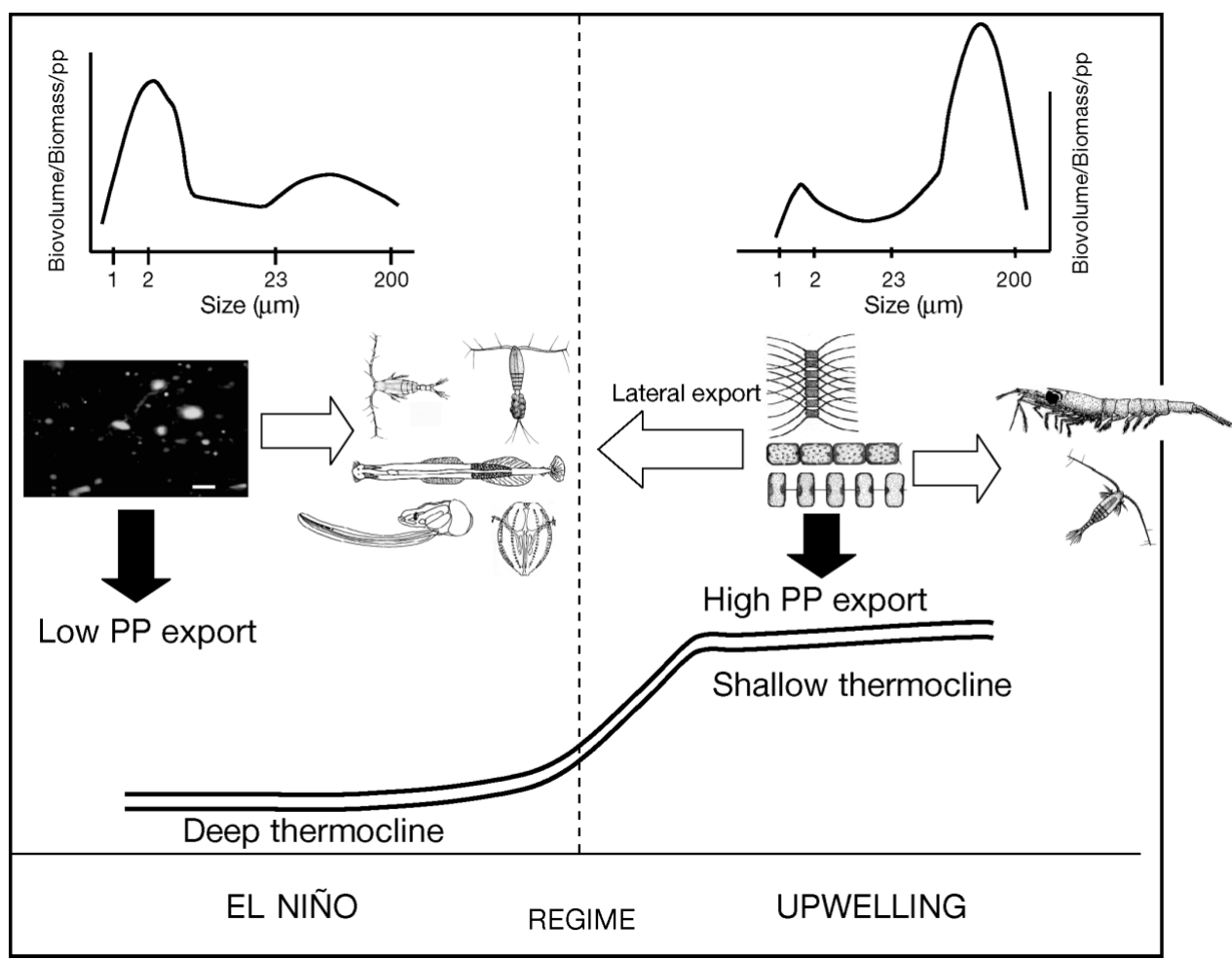

Fig. 6. Schematic model of changes of export/production rates, phytoplankton biomass size-spectrum and phytozooplankton assemblage structure associated with El Niño and normal upwelling events in coastal waters off Antofagasta. PP: primary productivity

warm periods, the 15 to $16^{\circ} \mathrm{C}$ isotherms deepen, resulting in a suppression of coastal upwelling, low biomass and $\mathrm{PP}$, and domination by pico-and nanophytoplankton size classes in inshore waters. In summary, during El Niño in the northern Humboldt Current System, the dominance of smaller phytoplankton size-fractions, and their larger contribution to both PP and biomass, leads us to believe that biological and physiological shifts occur in phytoplankton assemblages in order to counteract the change in prevailing physical and chemical conditions.

Acknowledgements. The authors thank all the researchers involved in the project for their cooperation in the collecting of samples or for providing the supporting data used in this study. This study was supported by FONDECYT Grants $\mathrm{N}^{\circ}$ 5960002-1996, 1000419-2000, No 150100007-2002, and CONICYT - Beca de Apoyo Tesis Doctoral 2002 to J.L.I. We thank T. Pennington for his valuable comments on the manuscript and for checking the English. Special thanks to J. Ryan for providing Fig. 1.

\section{LITERATURE CITED}

Arata A (1980) Datos para proyectos de energía solar. Departamento de Publicaciones de la Universidad Técnico Federico Santa María, Valparaíso
Barber RT, Sanderson M, Lindley ST, Chai F, Newton J, Tress CC, Foley DG, Chavez F (1996) Primary productivity and its regulation in the equatorial Pacific during and following the 1991-1992 El Niño. Deep-Sea Res 43:933-969

Brown PC, Field JG (1986) Factors limiting phytoplankton production in a nearshore upwelling area. J Plankton Res 8:55-68

Calienes R, Guillén O, Lostaunan N (1985) Variabilidad espacio temporal de clorofila, productividad primaria y nutrientes frente a la costa peruana. Bol Inst Mar Perú 10:1-44

Chavez FP (1989) Size distribution of phytoplankton in the central and eastern tropical Pacific. Global Biogeochem Cycles 3:27-35

Chavez FP, Pennington JT, Castro CG, Ryan JP and 6 others (2002) Biological and chemical consequences of the 1997-1998 El Niño in central California waters. Prog Oceanogr 54:205-232

Chisholm SW (1992) Phytoplankton size. In: Falkowski PG, Woodhead AD (eds) Primary productivity and biogeochemical cycles in the sea. Plenum Press, New York, 213-237

Edler L (1979) Recommendations on methods for marine biological studies in the Baltic Sea. Phytoplankton and chlorophyll. Baltic Mar Biol Ser 5:1-38

González H, Daneri G, Figueroa D, Iriarte JL and 5 others (1998) Primary production and its fate in the pelagic food web and deep-sea, and ocean-atmosphere $\mathrm{CO}_{2}$ exchange in the northern Humboldt Current $\left(23^{\circ} \mathrm{S}\right)$ : possible effects of the 1997-1998 El Niño in Chile. Rev Chil Hist Nat 71: $429-458$

González HE, Sobarzo M, Figueroa D, Nothig EM (2000) Composition, biomass and potential grazing impact of 
the crustacean and pelagic tunicates in the northern Humboldt Current area off Chile: diferences between El Niño and non-El Niño years. Mar Ecol Prog Ser 195: 201-220

Gundersen K (1991) Sampling precision and preservation of sediment trap material. In: Wassmann $P$, Heikanen AS, Lindahl O (eds) Sediment trap studies in the nordic countries, Nurmiprint Oy, Nurmijarui 2, p 6-35

Hall JA, Vincent WF (1990) Vertical and horizontal structure in the picoplankton communities of a coastal upwelling system. Mar Biol 106:465-471

Hasle GR (1978) The inverted microscope method. In: Sournia A (ed) Phytoplankton manual. Monographs on oceanographic methodology. UNESCO, Paris, p 88-96

Iriarte JL, Pizarro G, Troncoso VA, Sobarzo M (2000) Primary production and biomass of size-fractionated phytoplankton off Antofagasta, Chile $\left(23-24^{\circ} \mathrm{S}\right)$ during pre-El Niño and El Niño 1997. J Mar Syst 26:37-51

Lee C, Hedges JI, Wakeham SG, Zhu N (1992) Effectiveness of various treatments in retarding microbial activity in sediment trap material and their effects on the collection of swimmers. Limnol Oceanogr 37:117-130

Legendre L, Rassoulzadegan F (1995) Plankton and nutrient dynamics in marine waters. Ophelia 41:153-172

Marin VH, Olivares GR (1999) Estacionalidad de la productividad primaria en Bahía Mejillones del sur (Chile): una aproximación proceso funcional. Rev Chil Hist Nat 72: 629-642

McPhaden MJ (1999) Genesis and evolution of the 1997-98 El Niño. Science 283:950-954

Montagnes DJS, Berges JA, Harrison P, Taylor FJR (1994) Estimating carbon, nitrogen, protein, and chlorophyll a from volume in marine phytoplankton. Limnol Oceanogr 39:1044-1060

Montecino V, Quiroz D (2000) Specific primary production and phytoplankton size structure in an upwelling area off Chile $\left(30^{\circ} \mathrm{S}\right)$. Aquat Sci 62:364-380

Olivieri RA, Chavez FP (2000) A model of plankton dynamics for the coastal upwelling system of Monterey Bay, California. Deep-Sea Res 47:1077-1106

Ortlieb L, Escribano R, Follegati R, Zúñiga $O$ and 5 others (2000) Recording of ocean-climate changes during the last 2000 years in a hypoxic marine environment off northern Chile $\left(23^{\circ} \mathrm{S}\right)$. Rev Chil Hist Nat 73:221-242

Editorial responsibility: Otto Kinne (Editor), Oldendorf/Luhe, Germany
Parsons TR, Maita Y, Lalli CM (1984) A manual of chemical and biological methods for seawater analysis. Pergamon Press, Oxford

Pizarro G, Iriarte JL, Montecino V (2002) Mesoscale primary production and bio-optical variability off Antofagasta (23-24 $\left.{ }^{\circ} \mathrm{S}\right)$ during the transition to El Niño 1997-1998. Rev Chil Hist Nat 75:201-215

Rassoulzadegan F, Sheldon RW (1986) Predator-prey interactions of nanozooplankton and bacteria in an oligotrophic marine environment. Limnol Oceanogr 31:1010-1021

Rodriguez L, Marín V, Farías M, Oyarce E (1991) Identification of an upwelling zone by remote sensing and in situ measurements. Mejillones del Sur Bay (Antofagasta, Chile). Sci Mar 55:467-473

Romero OE, Hebbeln D, Wefer G (2001) Temporal and spatial variability in export productionin the SE Pacific Ocean: evidence from siliceous plankton fluxes and surface sediment assemblages. Deep-Sea Res I 48:2673-2697

Sobarzo M, Figueroa D (2001) The physical structure of a cold filament in a Chilean upwelling zone (Peninsula de Mejillones, Chile, 23 S). Deep-Sea Res 48:2699-2726

Takahashi M, Bienfang PK (1983) Size-structure of phytoplankton biomass and photosynthesis in subtropical Hawaiian waters. Mar Biol 76:203-211

Thomas AC, Blanco JL, Carr ME, Strub PT, Osses J (2001) Satellite-measured chlorophyll and temperature variability off northern Chile during the 1996-1998 La Niña and El Niño. J Geophys Res 106:899-915

Ulloa O, Escribano R, Hormazabal S, Quiñones R, González R, Ramos $M$ (2001) Evolution and biological effects of the 1997-98 El Niño in the upwelling ecosystem off northern Chile. Geophys Res Lett 28:1591-1594

Urban JL, McKenzie CH, Deibel D (1993) Nanoplankton found in fecal pellets of macrozooplankton in coastal Newfoundland waters. Bot Mar 36:267-281

Utermöhl H (1958) Zur Vervollkommnung der quantitativen Phytoplankton-Methodik. Mitt Int Ver Theor Angew Limnol 9:1-39

Verity PG, Robertson CY, Tronzo CR, Andrews MG, Nelson JR, Sieracki ME (1992) Relationship between cell volume and the carbon and nitrogen content of marine photosynthetic nanoplankton. Limnol Oceanogr 37:1434-1446

Zar JH (1984) Biostatistical analysis, 2nd edn. Prentice-Hall, Englewood Cliffs, NJ

Submitted: February 21, 2003; Accepted: December 2, 2003 Proofs received from author(s): March 12, 2004 